\title{
TÜKETIM-GELİR ORANININ
}

DURAĞANLIĞI:

\section{TÜRKIYE ÖRNEĞİ}

\section{Ayşe ARI}

Yrd.Doç.Dr. Niğde Üniversitesi

İktisadi ve İdari Bilimler Fakültesi

İktisat Bölümü

ayse.ari@istanbul.edu.tr

\section{Burcu ÖZCAN}

Doç.Dr. Fırat Üniversitesi

İktisadi ve İdari Bilimler Fakültesi

İktisat Bölümü

bozcan@firat.edu.tr

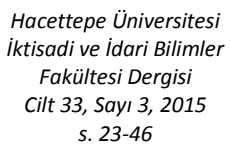

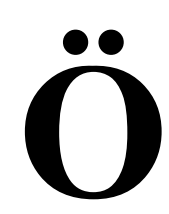

z: Bu çalışmada Türkiye'de tüketim-gelir oranının durağan olup olmadığ sorgulanmaktadır. $\mathrm{Bu}$ amaçla 1955-2010 dönemi, Zivot ve Andrews (1992) (ZA), Lumsdaine ve Papell (1997) (LP), Lee ve Strazicich (2003, 2004) (LM) ve Kapetanios vd. (2005) tarafından geliştirilen yapısal kırılmalı birim kök testleri ile Kapetanios $v d$. (2003) (KSS) tarafindan geliştirilen doğrusal olmayan birim kök testi ile analiz edilmiştir. Bulgular, bir ve iki kırılmalı LM testinde Model A ile KSS testinde sabitli ve trendli model hariç, tüketim-gelir oranında birim kökün varlığını ortaya koymuştur. $\mathrm{Bu}$ durumda genel itibariyle tüketim-gelir oranının bir sabite yakınsamayacağı dolayısıyla şokların hanehalkının tüketim ve tasarruf davranışları üzerinde kalıcı etkilere sahip olacağı söylenebilecektir. Ayrıca nispi gelir hipotezi, sürekli gelir hipotezi ve ömür boyu gelir hipotezlerinin aksine mutlak gelir hipotezinin geçerliliğinden bahsedilebilir.

Anahtar Sözcükler: Tüketim-gelir oranı, birim kök testleri, yapısal kurılma. 


\section{THE STATIONARITY OF CONSUMPTION-INCOME}

RATIO: EVIDENCE

\section{FROM TURKEY}

\author{
Ayşe ARI \\ Assist.Prof.Dr., Niğdel University \\ Faculty of Economics and \\ Administrative Sciences \\ Department of Economics \\ ayse.ari@istanbul.edu.tr

\section{Burcu ÖZCAN} \\ Assoc.Prof.Dr. Furat University \\ Faculty of Economics and \\ Administrative Sciences \\ Department of Economics \\ bozcan@firat.edu.tr
}

\author{
Hacettepe University \\ Journal of Economics \\ and Administrative \\ Sciences \\ Vol 33, Issue 3, 2015 \\ pp. 23-46
}

bstract: In this study we
investigate the stationarity of
consumption-income ratio for
Turkey. For this aim, the period of 1955-2010 is examined by using the structural break unit root tests, proposed by Zivot and Andrews (1992) (ZA), Lumsdaine and Papell (1997) (LP), Lee and Strazicich (2003, 2004) (LM), and Kapetanios et al. (2005) and also a non linear unit root test developed by Kapetanios et al. (2003). The results provide evidence of unit root exceptions with one and two break LM unit root test in case of Model A and KSS unit root test in case of constant and trend model. As a result of these findings, we can generally assert that the consumptionincome ratio is not mean reverting and thus the political shocks will have permanent effects on the consumption and saving behaviours of households. Besides, these results support the absolute income hypothesis in contrast to the relative income hypothesis, the permanent income hypothesis and the life cycle hypothesis.

Keywords: Consumption-income ratio, unit root tests, structural break 


\section{GíRis}

Tüketim-gelir oranının ya da ortalama tüketim eğiliminin (APC) uzun dönem davranışı hem teorik hem de ampirik literatürde yoğun bir tartışma konusu haline dönüşmüştür. Durağan bir APC, tüketim ve gelir arasında bir uzun dönem denge ilişkisinin varlığını ortaya koymaktadır ki, böylesi bir durumda APC uzun dönemde bir sabite yakınsamaktadır. APC'nin ortalamasına geri dönüp dönmediği tüketim fonksiyonunun ampirik modellemesini, tasarruf öğesinin davranış ve iş çevrimlerinin doğasına ilişkin algılayışımızı ve iktisat politikası uygulamalarını etkilemektedir (Sarantis, Stewart, 1999: 309). Örneğin, durağan olmayan bir APC serisi, politik şokların hanehalkının tüketim ve tasarruf davranışları üzerinde sürekli etkilere sahip olacağını ifade etmektedir.

APC'nin ve dolayısıyla tasarruf oranının bütünleşme derecesi farklı ülkeler arasında gözlemlenen global dengesizlikler nedeni ile önem arz eden bir konudur. Örneğin, büyük hacimli ticaret açılarının en önemli nedenlerinden biri ulusal tasarruf düzeyindeki azalıştır. Bütçe açıkları da gelişmiş ya da gelişmekte olan ülkeler için ticaret açıklarına yol açabilir. Böylesi bir durumda yatırım talebinin yabancı sermaye ile finanse edilme olasılığı söz konusudur ki, sonuç daha yüksek ulusal faiz oranları ve döviz kurunun değerlenmesidir. Bu durumun, nihayetinde ihracatı olumsuz etkilemesi olasıdır (Cerrato $v d ., 2013: 102)$

Yakın dönemde, uygulamalı iktisat sahasında birçok çalışma tüketim gelir oranında birim kökün varlığını test etmeye özel önem atfetmiştir. Tüketim-gelir oranının stokastik özelliklerinin araştırılması, tüketim teorilerinin APC oranına ilişkin temel varsayımlarının ve aynı zamanda teorilerin kendilerinin geçerlilikleri hakkında önemli kanıtlar sunduğu için önem arz etmektedir. Bu çalışmanın amacı da tüketimgelir oranının durağanlığını Türkiye için sınamaktır. Bu doğrultuda 1955-2010 dönemi, Zivot ve Andrews (1992), Lumsdaine ve Papell (1997) ile Lee ve Strazicich (2003, 2004) tarafından geliştirilen yapısal kırılmalı birim kök testleri kullanılarak analiz edilmektedir.

APC'nin durağanlığının araştırılması, Türkiye ekonomisi için de önemli politik çıkarımlar ortaya koyacaktır. Durağan bir APC, "Nisbi Gelir Hipotezi”, "Sürekli Gelir Hipotezi" ve "Yaşamboyu Gelir Hipotezi”ni destekleyici yönde bulgular ortaya koyacaktır. Bu teoriler, Keynes tarafindan öne sürülen "Mutlak Gelir Hipotezi”nin tersine APC'nin kısa dönemde azalan, fakat uzun dönemde sabit bir seyir izlediğini ifade etmektedirler. Durağan bir APC, Türkiye'de tüketicilerin tüketim ve tasarruf 
davranışlarını etkilemek üzere uygulanan politikaların kalıcı bir etkiye sahip olamayacaklarını göstermektedir. Fakat tersine, durağan olmayan bir APC ise "Mutlak Gelir Hipotezi”ni doğrulayıcı bir şekilde uygulanan politikaların söz konusu değişkenler üzerinde kalıcı etkiye sahip olacaklarını göstermektedir. Ayrıca, bulgular toplam tüketimi etkilemede Türkiye'de para politikalarının mı yoksa maliye politikalarının mı daha etkili olacağını da ortaya koyacaktır. Bu bağlamda, Sürekli Gelir ve Ömür Boyu Gelir hipotezlerine göre tüketim, sürekli gelirden ve para politikasındaki değişikliklerden büyük oranda etkilenen servet düzeyi tarafından belirlendiği için, para politikaları toplam tüketimi belirlemede maliye politikalarına kıyasla daha etkindir. Ayrıca, tüketiciler Nispi Gelir Hipotezi, Sürekli Gelir Hipotezi ve Yaşam Boyu Gelir Hipotezinde varsayıldığı üzere, zaman boyunca tüketimlerini düzleştirmeye çalıştıkları için toplam talep yönetimi kısa dönem harcaması üzerinde daha az etkilidir. Başka bir ifade ile, ihtiyari talep yönetimi daha az etkindir.

Çalışmanın izleyen bölümlerinde ilk olarak tüketim teorileri açıklanacaktır. İkinci bölümde ise tüketim-gelir oranının durağanlığına ilişkin literatürde yer alan çalışmalara yer verilecektir. Üçüncü bölümde, çalışmada tercih edilen metodolojiden bahsedilecektir. Dördüncü bölümde analizlerden elde edilen bulgulara değinilirken, sonuç kısmı ile çalışma sona erecektir.

\section{TÜKETIM TEORILLERI VE ORTALAMA TÜKETIM EĞİLIMİ}

Tüketim teorilerinin ampirik geçerliliği, APC serisinde birim kökün var olup olmadığı ile sınanabilmektedir. APC'de görülen birim kök ya da durağan dışılık Keynesyen (1936)'in “Mutlak Gelir Hipotezi”, Deaton (1977)'un 'Zorunlu-İstek Dışı Tasarruf Teorisi” ve Marksist "Yetersiz Tüketim Teorisi” (Underconsumption Theory) ile uyumludur. Çünkü bu teoriler APC'nin durağan olmadığını ya da uzun dönemde bir sabite yakınsamayacağını ileri sürmektedirler. Hâlbuki Duesenberry (1952)'nin "Nispi Gelir Hipotezi”, Friedman (1957)'ın "Sürekli Gelir Hipotezi” ile Ando ve Modigliani (1963)'nin "Ömür Boyu Gelir Hipotezi” yaklaşımları ise APC'nin durağan olduğunun ya da uzun dönemde sabit olduğunun altını çizmektedirler. Son grupta yer alan bu teoriler, tüketim ve gelir arasında bir uzun dönem denge ilişkisinin varlığından söz ettikleri için APC'nin ortalamasına geri dönen bir davranışa sahip olduğunu kabul etmektedirler. Bahsedilen tüketim teoriler kısaca şu şekilde açıklanabilir:

Keynes (1936), Genel Teori isimli eserinde tüketimle ilgili üç temel varsayımda bulunmuştur. Bunlardan ilki, tüketimin faiz haddi ile bir ilişkisinin olmadığı ve sadece gelir düzeyine bağlı olduğudur. İkincisi, harcanabilir gelir arttıkça tüketimin 
de arttığı fakat tüketimdeki artışın gelirdeki artıştan daha küçük olduğudur. Başka bir ifade ile temel psikolojik kanun diye adlandırılan harcanabilir kişisel gelir arttıkça tüketimin gelirden daha az arttığı varsayımı söz konusudur. Üçüncü varsayım ise, harcanabilir gelir artıkça gelirin, tüketim amacıyla kullanılan kısmının $(\mathrm{C} / \mathrm{Y}$ şeklinde ifade edilen ortalama tüketim eğiliminin) azalacağı, bunun yerine ise ortalama tasarruf eğiliminin ( $\mathrm{C} / \mathrm{S}$ șeklinde ifade edilen) artacağıdır.

Keynesyen tüketici miyopik özelliğe sahiptir. Bir başka deyişle cari tüketim düzeyi cari gelirin bir fonksiyonudur. Nispi gelir hipotezi, sürekli gelir hipotezi ve ömür boyu gelir hipotezi yaklaşımlarında ise tüketici ileriyi gören (forward looking) bir özelliğe sahiptir. Bu nedenle cari dönem tüketim kararı, cari dönem gelirin bir fonksiyonu olmayıp sürekli gelir, ömür boyu gelir ya da nispi gelir şeklinde farklı gelir türlerinden etkilenmektedir. Bu teoriler kısa dönemde değişken olan APC'nin uzun dönemde sabit bir değer alacağını tüketim bulmacasından yola çıkarak açıklamaktadırlar. Kısa dönemde gelir artınca mutlak gelir hipotezinin öngördüğü şekilde ortalama tüketim eğiliminin azaldığı, fakat uzun dönemde mutlak gelir hipotezinin tersine gelir artınca ortalama tüketim eğiliminin sabit kaldığı şeklindeki bulgu tüketim bulmacası olarak adlandırılmaktadır. Keynes’ten sonra gelen iktisatçılar önermiş oldukları tüketim teorileri ile tüketim bulmacasını açıklamaya çalışmışlardır.

Örneğin bunlardan biri olan Duesenberry (1952)'nin öne sürdüğü nispi gelir hipotezine göre, tüketim kararları nispi tüketim kalıpları ya da "komşularla boy ölçüşmek" (keeping up with the Joneses) şeklinde bilinen gösteriş etkisi tarafından belirlenmektedir. Duesenberry için bir kişinin tüketim harcamalarını artırma arzusunun gücü kendi harcamasının, yakalamayı arzu ettiği kişilerin harcamalarının ağılıklı ortalamasına oranının bir fonksiyonudur. Nispi gelir hipotezi, düşük gelir grubundaki kişilerin yüksek gelir grubundaki kişilerin tüketim davranışlarını taklit etmeye çalıştıklarını ve bu nedenle ilk grubun, ikinci guruba göre daha yüksek APC'ye sahip olduğunu ileri sürmektedir. Ayrıca teori kısa dönemde iktisadi dalgalanmalar nedeniyle gelir değişince, tüketimin sadece cari gelire değil önceki dönemin en yüksek gelir düzeyine bağlı olarak değiştiğini varsaymaktadır.

Zamanlararası tüketim teorisine dayalı olan ömür boyu gelir hipotezi ve sürekli gelir hipotezi yaklaşımları ise tüketim düzleştirmesi hakkında açıklama sunmaktadırlar. Tüketicinin gelecekteki veya bugünkü gelirinde meydana gelen değişmenin tüketim üzerindeki etkisini her iki döneme yayarak hafifletmesi tüketim düzleştirmesi şeklinde adlandırılmaktadır. Her iki yaklaşımda cari gelir yerine birer uzun dönem olgusu şeklinde beklenen ömür boyu ya da sürekli gelir kavramları dikkat çekmektedir. Bu 
modellerde geçici olduğu düşünülen cari gelirdeki beklenmeyen değişiklikler cari tüketimi etkilememektedir (Baykara, Telatar, 2012: 2).

Bu açıklamalar 1şığı altında, Ando ve Modigliani (1963) tarafından ileri sürülen ömür boyu gelir hipotezinde " $t$ " dönemindeki tüketim, tüketicilerin " $t$ " döneminde elde ettikleri gelire değil ömür boyunca elde etmeyi bekledikleri gelire bağlıdır. Kısaca, bugünkü tüketim gelirin bugünkü değerine bağlıdır. Bu teoriye göre, kişiler hayatlarının çalışma döneminde emeklilik dönemine kıyasla daha fazla gelir elde etmektedirler. Bu nedenle tüketim düzleştirmesi yapmak için hayatlarının çalışma döneminde pozitif tasarruf yapmakta ve bu tasarruf ile de emeklilik döneminde tüketimin geliri aşan kısmını finanse etmektedirler. Ömür boyu gelir hipotezi yaklaşımı tüketim bulmacasını, tüketimi gelirin yanı sıra servet ile ilişkilendirerek çözmektedir. Başka bir ifade ile kısa dönemde servet veri iken tüketim gelire bağlı olarak değişmektedir. Uzun dönemde ise, gelir artınca servetin de artması sonucu tüketim fonksiyonu yukarıya kaymakta, gelir ve tüketim birlikte arttığı için ortalama tüketim eğilimi sabit kalmaktadır.

Friedman (1957)'ın sürekli gelir hipotezi ise, ömür boyu gelir hipotezi gibi bireylerin tüketim düzleştirmesi yaptıkları ve dolayısı ile tüketimin sürekli gelirle oransal olarak değiştiğini kabul etmektedir. Sürekli gelir, bireylerin sahip oldukları beşeri ve beşeri olmayan servet ile her yıl elde etmeyi bekledikleri ortalama gelire eşittir. Sürekli gelir hipotezi tüketim bulmacasına şu şekilde bir çözüm sunmaktadır: Uzun dönemde iktisadi dalgalanmanın genişleme ve daralma aşamalarındaki pozitif ve negatif geçici gelir büyüklüklerinin birbirlerini telafi ettikleri uzun dönemde ölçülen gelir, sürekli gelire eşitlenmektedir. Bu nedenle ortalama tüketim eğilimi uzun dönemde değişmemektedir. Kısa dönemde ise genişleme yıllarında ölçülen gelir, sürekli gelirden büyük olmaktadır. Tüketimin sürekli gelirin bir fonksiyonu olduğu hususu dikkate alındığında genişleme yıllarında ortalama tüketim eğilimi daha küçük olmaktadır. Bu durumda kısa dönemde gelir artınca ortalama tüketim eğilimi mutlak gelir hipotezinin öne sürdüğü gibi düşmektedir. İktisadi dalgalanmanın daralma dönemlerinde ise, geçici gelir negatif olduğu için ölçülen gelir, sürekli gelirden küçüktür. Tüketimin sürekli gelirin bir fonksiyonu olduğu dikkate alındığında, daralma yıllarında ortalama tüketim eğilimi daha büyüktür. Bu nedenle kısa dönemde gelir azalınca ortalama tüketim eğilimi yükselmektedir.

Açıklanan bu teorilerin geçerlilikleri aynı zamanda tüketim üzerinde maliye ya da para politikalarından hangisinin daha etkili olduğunu da ortaya koyacaktır. Çünkü Baykara ve Telatar (2012: 9) tarafindan belirtildiği üzere, sürekli gelir ve ömür boyu gelir hipotezlerine göre para politikaları mutlak gelir hipotezinin tersine, toplam 
tüketimi belirlemede maliye politikalarından daha büyük role sahiptir. Bu farkın temel nedeni bu yaklaşımların tüketimi, para politikası uygulamalarından daha fazla etkilenen sürekli gelirin ya da servetin bir fonksiyonu olarak görmeleridir. Üstelik sürekli gelir ve ömür boyu gelir yaklaşımlarında sadece şimdiyi ve geleceği umursayan tüketiciler için beklentiler önemli rol oynadığı için şokların kaynağı da önem kazanmaktadır. Tüketiciler bir şokun sürekli ya da geçici olması halinde farklı tepki vereceklerdir. Tüketim genellikle geçici şoklardan ziyade sürekli değişikliklerden sorumludur. Vergilerdeki geçici bir değişiklik, tüketim üzerinde etkili olmayacağı için maliye politikası etkin olmayacaktır. Bu durumun tersine, mutlak gelir hipotezinin azalan ortalama tüketim eğilimi varsayımı, tüketicilerin sadece kısa dönemi dolayısıyla cari geliri önemsediklerini ve tüketimi belirlemede maliye politikalarının uygulanabilir olduğuna işaret etmektedir.

\section{LITERATÜR TARAMASI}

Makro ekonomik değişkenlerde stokastik trendin varlığının araştırılması, Nelson ve Plosser (1982)'in Birleşik Devletlere ait temel makro ekonomik değişkenlerin zaman serisi özelliklerinin incelendiği çalışmadan itibaren iktisatçılar arasında oldukça ilgi çekici hale gelmiştir.

APC'nin durağanlığını analiz eden ilk dönem çalışmaları Dickey-Fuller (DF) ve Augmented Dickey-Fuller (ADF) tipi geleneksel zaman serisi birim kök testlerini kullanmışlardır. Bunların arasında örneğin, Drobny ve Hall (1989), Hall ve Patterson (1992) ile Molana (1991) Birleşik Krallıklar için, Horioka (1997) Japonya için, Bjornland (1999) ise Norveç için APC'nin durağan olmadığını tespit etmiştir. Campbell (1987), Lettau ve Ludvigson (2001), Slesnick (1998), Blinder $v d$. (1985) ile King $v d$. (1991) Birleşik Devletler için, Ungern-Stenberg (1986) ise Almanya için APC'nin durağan olduğu sonucuna varmıştır. Cook (2003) ise Park ve Fuller (1995) tarafından geliştirilmiş olan ağırlıklandırılmışs simetrik Dickey-Fuller testi ile Shin ve So (2001) tarafından geliştirilen tekrarlı ortalamaya göre düzeltilmiş DF testini kullanarak Birleşik Krallıklar için APC'nin durağan olmadığı yönünde sonuç elde etmiştir. Yakın döneme ait çalışmalardan biri olan Fallahi (2012) ise, 23 OECD ülkesi için 1950-2007 dönem aralığı boyunca ADF ile Ng ve Perron (2001) testlerine (MZ $\alpha$, MZt, MSB ve MPT) ilave olarak üç farklı bootstrap tekniği ile \%90 güven aralıkları oluşturarak durağanlık analizi yolu ile APC'nin stokastik özelliklerini incelemiştir. Sonuçların çoğu APC serilerinin durağan olmadığı yönündedir. 
Zaman içerisinde literatür yapısal kırılmalı birim kök, panel birim kök ve doğrusal olmayan birim kök testlerinin kullanılması doğrultusunda gelişme göstermiştir. Örneğin, yapısal kırılmaları dikkate alan çalışmalardan Cook (2005), 20 OECD ekonomisi için Lee ve Strazicich $(1999,2003)$ tarafından geliştirilen bir ve iki kırılmalı LM birim kök testlerini uygulayarak APC'nin durağan olduğu yönünde kanttlar elde etmiştir. Burada 14 ülke için iki kırılmalı durumda, 6 ülke için ise tek kırılmalı durumda durağanlık tespit edilmiştir. Gomes ve Franchini (2009) tarafından yapılan çalışma ise, 10 Güney Amerika ülkesi için 1951-2003 döneminde geleneksel ADF ile Maddala ve Wu (MW testi, 1999) testlerine ilave olarak yapısal kırılmaları dikkate alan minimum LM birim kök testlerini kullanmıştır. ADF ve MW testleri birim kökün varlığı yönünde kanıtlar sunarken yapısal kırılmaları dikkate alan LM testi ise sadece Uruguay için APC'nin birim kök içerdiğini göstermiş̧ir.

Doğrusal dişılığı ve asimetriyi dikkate alan literatürden Cook (2002), OECD ülkeleri için APC'nin durağanlığını asimetrik ortalamaya dönüş ihtimalinin dikkate alındığı MTAR (1) birim kök testini kullanarak incelemiştir. Elde edilen sonuçlar çoğu ülke için APC'nin ortalamasına geri döndüğünü ortaya koymuştur. Özellikle, Avustralya ve İspanya için ise oldukça yüksek anlamlılığa sahip asimetrik ortalamaya geri dönüş eğilimi saptanmıştır. Cerrato $v d$. (2013) ise 24 OECD ve 33 OECD-dışı ülke için 1951-2003 dönemi boyunca Cerrato $v d$. (2009) tarafindan geliştirilen heterojen doğrusal olmayan panel birim kök testi ile Pesaran (2007) tarafindan geliştirilen yatay kesit bağımlılığını dikkate alan doğrusal panel birim kök testini kullanmıştır. Sonuçlar, serilerin \%78'inin durağan olmadığını ortaya koymakla beraber OECD dışı ülkelerin \%74'ü birim kök içerirken, OECD üyesi ülkelerde bu oran \%83'tür. Baykara ve Telatar (2012) tarafından yapılan çalışma ise, 14 geçiş ekonomisi için APC serilerinin durağanlığını Kapetanios $v d$. (2003) ile Sollis $v d$. (2002)'ye ait birim kök testleri kullanarak incelemiştir. Sonuçlar tüm ülkeler için APC serilerinin durağanlığını ortaya koymuştur. Asimetriyi dikkate alan bir diğer çalışma örneği ise, Tsionas ve Christopoulos (2002)'a aittir. Çalışma 14 AB üye ülkesi için 1960-1999 dönemi boyunca panel birim kök testleri (Im vd., 1997; Maddala, Wu, 1999; Haris, Tzavalis, 1999) ve asimetrik birim kök testi (Caner, Hansen, 2001) kullanmıştır. Zaman serisi ADF testleri ve panel birim kök testleri, birim kök olduğu yönünde sonuçlar ortaya koyarken, asimetriyi dikkate alan birim kök testi ise en azından bir rejimde durağanlığa işaret etmiştir.

Panel birim kök literatüründen Sarantis ve Stewart (1999)'a ait çalışma 20 OECD ülkesi için Im $v d$. (1997) ile Taylor ve Sarno (1998) panel birim kök testlerini kullanmış ve tüm OECD ülkelerinin durağan olmayan APC serilerine sahip olduklarını 
saptamıştır. Jin (1995) ise, Levin $v d$. (2002) tarafından geliştirilen LLC panel birim kök testi ile 12 OECD ülkesi için 1960-1988 dönemi boyunca gelir ve tüketim arasında eşbütünleşme saptamıştır ki bu durum OECD ülkelerinin APC serilerinin durağanlığına işaret etmektedir. Romero-Avila (2008)'ya ait bir diğer panel çalışma ise, 1960-2005 dönemi boyunca 23 OECD ülkesi için APC'nin durağanlığını Pesaran (2003), Smith vd. (2004) ve Hadri (2000) tarafindan geliştirilen panel birim kök testleri ile incelemiştir. Elde edilen bulgular, OECD ülkelerinin APC serilerinin birim kök içerdiğini ortaya koymuştur. Romero-Avila (2009) tarafından ele alınan bir başka çalışmada ise, 23 OECD ülkesi için 1960-2005 dönemi boyunca APC'nin stokastik özellikleri yakın döneme ait panel birim kök ve durağanlık testleri kullanılarak incelenmiştir. Yapısal kırılmaları dikkate almayan panel birim kök testleri birim kökün varlığını ortaya koymuştur. Fakat Carrion-i Silvestre $v d$. (2005) tarafından geliştirilen yapısal kırılmaları dikkate alan panel durağanlık testi ise, yatay kesit bağımlılı̆̆ının dikkate alındığı durum için APC serilerinin rejim durağanlığına sahip olduğunu tespit etmiştir. Yatay kesit bağımlılı̆̆ını dikkate alan SURADF panel birim kök testini kullanan Liao $v d$. (2011) ise 24 OECD ülkesinden 22'sinin APC serilerinin ortalamasına geri dönen (durağan) bir davranışa sahip olduğunu bulmuştur. Yılancı vd. (2013) tarafından yapılan bir başka panel çalışma ise 9 Güneydoğu Asya ülkesi için (Bruney, Endonezya, Filipinler, Kamboçya, Laos, Malezya, Singapur, Tayland ve Vietnam) 1970-2010 dönemine ait APC serilerinin stokastik özelliklerini Im $v d$. (2005)'nin geliştirmiş olduğu panel LM birim kök testleri ile incelemiş ve durağanlık yönünde güçlü kanıtlar saptamıştır. Son olarak Gözgör (2013), 11 Merkez ve Doğu Avrupa ülkesi (Bulgaristan, Hırvatistan, Çek Cumhuriyeti, Estonya, Macaristan, Letonya, Litvanya, Polonya, Romanya, Slovakya ve Slovenya) için APC'nin durağanlığını yatay kesit bağımlılı̆̆ını dikkate alan heterojen panel birim kök testleri ve düzeltilmiş ADF birim kök testi (Maddala, Wu, 1999; Choi, 2001; Pesaran, 2007) kullanarak 1997-Mart- 2012 Eylül dönemi için araştırmıştır. Elde edilen sonuçlar, Hırvatistan ve Slovenya hariç tüketim-gelir oranının ortalamasına geri dönen bir süreç izlediğini ortaya koymuştur.

\section{METODOLOJI}

Çalışmanın bu kısmında tüketim-gelir oranının durağanlığı Zivot ve Andrews (1992), Lumsdaine ve Papell (1997), Lee ve Strazicich $(2003,2004)$ ile Kapetanios $v d$. (2005) tarafından geliştirilen yapısal kırılmalı birim kök testleri ve Kapetanios $v d$. (2003) tarafından geliştirilen doğrusal olmayan KSS birim kök testi ile sınanmaktadır. Bu nedenle öncelikle söz konusu bu testler açıklanacaktır. 


\subsection{Zivot-Andrews Birim Kök Testi}

Zaman serilerinin yapısal değişimler geçirebileceğine işaret eden Perron (1989) birim kök analizlerinde yapısal kırılmaları dikkate alan bir model geliştirmiş̧ir. Ancak sonraki yıllarda Perron (1989)'un kırılma tarihinin bilindiği varsayımına dayanan modelini Zivot ve Andrews (1992) eleştirmiş ve kırılma tarihinin, içsel olarak belirlendiği tek kırılmalı modelini geliştirmiştir. Zivot-Andrews (ZA) birim kök testinde yer alan modeller şöyledir (Zivot, Andrews, 1992:254):

$$
\begin{gathered}
y_{t}=\mu+\beta t+\alpha y_{t-1}+\theta_{1} D U(\phi)+\sum_{i=1}^{k} c_{i} \Delta y_{t-i}+\varepsilon_{t}(\text { Model A) } \\
y_{t}=\mu+\beta t+\alpha y_{t-1}+\theta_{2} D T(\phi)+\sum_{i=1}^{k} c_{i} \Delta y_{t-i}+\varepsilon_{t} \text { (Model B) } \\
y_{t}=\mu+\beta t+\alpha y_{t-1}+\theta_{1} D U(\phi)+\theta_{2} D T(\phi)+\sum_{i=1}^{k} c_{i} \Delta y_{t-i}+\varepsilon_{t}(\text { Model C) }
\end{gathered}
$$

Model A düzeydeki yapısal değişimi dikkate alırken Model B eğimdeki, Model $\mathrm{C}$ ise hem düzey hem de eğimdeki yapısal değişimleri kapsamaktadır. Modellerde $T_{B}$ kırılma zamanını göstermekte, $\lambda=T_{B} / T$ ise kırılma noktasını vermektedir. $t=1,2, \ldots T$ olmak üzere $D U ; t \succ T_{B}$ durumunda 1 , diğer durumlarda sıfir değerini alan kukla değişken olup sabit terimdeki yapısal değişimi göstermektedir. $D T$ ise $t \succ T_{B}$ iken $t-T_{B}$ değerini alan diğer durumlarda ise sıfır değerini alan kukla değişkendir. $D T$ aynı zamanda eğimde meydana gelen yapısal değişimleri içermektedir. Zivot ve Andrews (1992) çalışmasında A, B ve C modellerine yer verse de uygulamada $\mathrm{A}$ ve $\mathrm{C}$ modeli üzerinde durulmaktadır.

\subsection{Lumsdaine-Papell Birim Kök Testi}

Çalışmalarda analiz edilen makro ekonomik serilerin uzun bir dönemi kapsaması durumunda tek kırılmanın dikkate alınmasının hatalı tahminlere yol açacağı gerekçesini dikkate alan Lumsdaine ve Papell (1997), Zivot ve Andrews (1992) birim kök testindeki modelleri iki kırılmaya izin verecek şekilde geliştirmiştir. Böylece Zivot-Andrews testindeki Model A ile Model C yerine düzeyde iki kırılmaya izin veren Model AA ile hem eğim hem de düzeyde iki kırılmaya izin veren Model CC oluşturulmuştur. Söz konusu modeller sırasıyla aşağıdaki gibidir:

$$
\Delta y_{t}=\mu+\beta t+\alpha y_{t-1}+w_{1} D U 1_{t}+\phi_{1} D T 2_{t}+\sum_{i=1}^{k} c_{i} \Delta y_{t-i}+\varepsilon_{t}
$$

Hacettepe University Journal of Economics and Administrative Sciences Vol 33, Issue 3, 2015

32 
$\Delta y_{t}=\mu+\beta t+\alpha y_{t-1}+w_{1} D U 1_{t}+w_{2} D U 2_{t}+\phi_{1} D T 2_{t}+\phi_{2} D T 1_{t}+\sum_{i=1}^{k} c_{i} \Delta y_{t-i}+\varepsilon_{t}(5)$

Bu modellerde $T_{B 1}$ ve $T_{B 2}$ 'nin sirasılyla birinci ve ikinci kırılma tarihlerini yansıttığı dikkate alındığında $D U 1_{t}, \quad t \succ T_{B 1}$ iken 1 değerini diğer durumlarda sıfır değerini alacak bir kukla değişkendir. $D U 2_{t}$ ise $t \succ T_{B 2}$ durumunda 1 , diğer koşullarda sıfır değerini alacak şekilde oluşturulmaktadır. $D T 1_{t}$ ise $t \succ T_{B 1}$ iken $(t-T B 1)$, diğer durumlarda sıfır; $D T 2_{t}$ ise $t \succ T_{B 2}$ iken $(t-T B 2)$ değerini alan, diğer durumlarda sıfır olan bir kukla değişkendir. Kırılma noktaları $\left(T_{B 1}\right.$ ve $\left.T_{B 2}\right)$ olarak , $\alpha$ 'nın $t$ istatistiklerini minimum yapan değerler seçilmektedir. Optimal gecikme uzunluğu ( $k$ ), Campell ve Perron (1991) ile Ng ve Perron (1995) tarafindan savunulan yöntemle $(t$ testi) belirlenmektedir.

\subsection{Lee- Strazicich Birim Kök Testi}

Tek kırılmalı birimkök testleri, kırılma durumunda sahte reddetmelere yol açabilecektir (Nunes $v d$., 1997). Lee ve Strazicich (2003) ise iki kırılmalı Lumsdaine ve Papell birimkök testinde de sahte reddetmenin söz konusu olacağını savunmuştur. Bir başka deyişle Lumsdaine-Papell testi iki kırılmayı dikkate almasına karşın temel hipotezin yapısal kırılmayı dikkate almaması nedeniyle eleștirilmiştir. Çünkü bu durumda yapısal kırılmaya sahip ancak durağan olmayan bir seri durağanmış gibi hatalı tahmin edilebilecektir. Lumsdaine-Papell testinin bu zayıflığını giderecek şekilde Lee ve Strazicich $(2003,2004)$, temel ve alternatif hipotez altında yapısal kırılmaya yer veren bir ve iki kırılmalı test geliştirmiştir. Böylece temel hipotezin reddedilmesi, gerçek anlamda durağanlığa işaret edecektir (Cook,2005: 56). Lee ve Strazicich (LM) testi, Schmidt ve Phillips (1992) tarafından geliştirilen Lagrange Çarpanları birim kök testine dayanmaktadır. Düzeyde tek kırılmaya izin veren Model A için regresyon şöyledir:

$$
y_{t}=\delta^{\prime} Z_{t}+X_{t} \quad X_{t}=\beta X_{t-1}+\varepsilon_{t}
$$

Burada $y_{t}$, APC'yi; $Z_{t}$, dışsal değişkenler vektörünü, $\varepsilon_{t}$ ise kalıntıları ifade etmektedir. Düzeyde tek kırılmaya izin veren Model A dikkate alındığında $Z_{t}=\left[1, t, D_{1 t}\right]^{\prime}$ biçimini almaktadır. $D_{1 t}$; kukla değişken olup düzeydeki yapısal kırılmayı temsil etmektedir. $t \geq T_{B}+1$ için 1 , diğer durumlarda sıfır değerini 
almaktadır. Model C için dışsal değişkenler vektörü $Z_{t}=\left[1, t, D_{1 t}, D T_{1 t}\right]^{\prime}$ biçimini almaktadır. $D T_{1 t} \quad$, eğimdeki yapısal kırılmayı temsil eden kukla değişken olup $t \geq T_{B}+1$ için $t-T_{B}$, diğer durumlar için sıfır değerini almaktadır.

İki kırılmayı dikkate alan LM testinde ise Model A için $Z_{t}=\left[1, t, D_{1 t}, D_{2 t}\right]^{\prime}$, Model C için $Z_{t}=\left[1, t, D_{1 t}, D T_{1 t}, D T_{2 t}, D_{2 t}\right]^{\prime}$ şeklini almaktadır. Model A için $D_{j t}$; düzeyde kırılmalara izin veren kukla değişkeni, $T_{B j}$ 'nin ise iki kırılmaya ait tarihi gösterdiği ve $j=1,2$ olduğu durumda; $t \geq T_{B j}+1$ iken $D_{j t} 1$, diğer durumlarda sıfır değerini almaktadır.

Veri yaratma süreci temel hipotez ve alternatif hipotez altında yapısal kırılmaları içermektedir. Model A için temel ve alternatif hipotezler aşağıdaki gibidir:

$$
\begin{aligned}
& H_{0}: y_{t}=\mu_{0}+d_{1} B_{1 t}+d_{2} B_{2 t}+y_{t-1}+\eta_{1 t} \\
& H_{1}: y_{t}=\mu_{1}+\gamma t+d_{1} D_{1 t}+d_{2} D_{2 t}+\eta_{2 t}
\end{aligned}
$$

Model C'de düzeydeki kırılmayı $D_{j t}$, eğimdeki kırılmayı ise $D T_{j t}$ kukla değişkeni temsil etmektedir. Bu modelde $t \geq T_{B j}+1$ için $D_{j t}, 1$ değerini alırken diğer durumlarda sıfır değerini almaktadır. $D T_{j t}$ ise, $t \geq T_{B j}+1$ iken $t-T_{B j}$, diğer durumlarda sıfır değerini almaktadır.

\subsection{Kapetanios (2005) Çoklu Kırılmalı Birim Kök Testi}

İktisadi analizlerde kullanılan zaman diliminin uzun bir dönemi kapsaması çeşitli reformların ve yapısal değişimlerin yaşanmasına imkân verdiğinden çoklu kırılmaları dikkate alan birim kök testlerine ihtiyaç duyulmaktadır. Kapetanios (2005) tarafından geliştirilen ve 5 kırılmaya izin veren birim kök testinde, sabit ve trendde kırılmaya izin veren Model C aşağıdaki şekilde gösterilebilmektedir:

$y_{t}=\mu_{0}+\mu_{1} t+\alpha y_{t-1}+\sum_{i=1}^{k} \gamma_{i} \Delta y_{t-i}+\sum_{i=1}^{m} \theta_{i} D U_{i, t}+\sum_{i=1}^{m} \varphi_{i} D T_{i, t}+\varepsilon_{t}$

Modelde yer alan $y_{t}$; APC'yi temsil etmektedir. $D U_{i, t}$ ve $D T_{\tilde{i}, t}$ ise kukla değişkenler olup aşağıdaki gibidir:

Hacettepe University Journal of Economics and Administrative Sciences Vol 33, Issue 3, 2015

34 


$$
\begin{gathered}
D U_{i, t}=\left\{\begin{array}{lc}
t>T_{b, i} \text { iken } & 1 \\
\text { Diğer durumlarda } & 0
\end{array}\right. \\
D T_{i, t}=\left\{\begin{array}{lc}
t>T_{b, i} \text { iken } & t-T_{b, i} \\
\text { Diğer durumlarda } & 0
\end{array}\right.
\end{gathered}
$$

\subsection{KSS Testi}

Kapetanios $v d$. (2003) tarafından geliştirilen KSS testi aşağıdaki ESTAR (üstel yumuşak geçişli otoregresif) modelinden hareket etmektedir:

$$
\Delta y_{t}=\gamma y_{t-1}+\left[1-\exp \left(-\theta y_{t-1}^{2}\right)\right]+\sum_{i=1}^{p} \beta_{i} \Delta y_{t-i}+\varepsilon_{t}
$$

Üstel geçiş fonksiyonu $\left[1-\exp \left(-\theta y_{t-1}^{2}\right)\right]$ şeklinde gösterilmekte olup sıfır ile bir arasında sinırlanmaktadır. Modelde sıfır hipotezi $H_{0}: \theta=0$ ve alternatif hipotez $\quad H_{A}: \theta>0$ yi test etmektedir. Ancak sıfır hipotezi altında $\gamma$ tanımlanmadığından doğrudan test edilemez. Bu nedenle $\mathrm{t}$ tipi bir istatistiğe ulaşmak amacıyla Kapetanios $v d$. (2003) yukarıdaki fonksiyonu birinci sıra Taylor açılımını uygulayarak yeniden parametrize etmişlerdir. Elde edilen regresyon şöyledir:

$$
\Delta y_{t}=\delta y_{t-1}^{3}+\sum_{i=1}^{p} \beta_{i} \Delta y_{t-i}+u_{t}
$$

Burada serinin durağanlı̆̆ $H_{0}: \delta=0$ sıfır hipotezine karşılık $H_{A}: \delta>0$ alternatif hipotezi altında test edilir. $\Delta y_{t}$; tüketim gelir oranı serisinin ortalamadan çıkarılmış halini ifade etmektedir. Kritik değerler Kapetanios $v d$. (2003) tarafindan hesaplanmıştır.

\section{VERİ SETİ VE BULGULAR}

Bu çalışmada 1955-2010 yılları arasında Türkiye'deki ortalama tüketim eğiliminin durağanlığı sınanmaktadır. Bu amaçla 2005 baz yıllı kişi başı tüketimin gayri safi yurtiçi hasılaya oranı dikkate alınmıştır. Veriler Penn World Table'dan elde

Açıklama [L1]: Bu zaman aralığ Türkiye ekonomisinde çeşitli reformların yapıldığı, dönüşüm ve kırılmaların yaşandığı dönemi kapsamaktadır. Bu nedenle çalıșmanın analiz için yapısal kırılmaları dikkate alması doğru ve önemlidir. Ancak seçilen yöntemler en fazla onemlidir. Ancak seçilen yöntemler en faz
iki yapısal kırılmaya izin vermektedir ve bulgulardan görüldüğü üzere bu kırılma tarihleri pratik ile çok da örtüşmemektedir. Halbuki bu zaman aralığı çok sayıda kırılmanın yaşandığı bir dönemdir. Bu nedenle çalışma çoklu kırılmalara izin veren birim kök testlerine de başvurmalıdır. Ayrıca çalışma tekil ülke zaman serisi uygulaması olduğundan ve tartışmanın temel odağının tüketim-gelir oranının birim kök olup olmamasına dayandığından, birim kök testleri sadece çoklu kırılmaları değil aynı zamanda literatüründe başvurduğu doğrusal olmayan ve asimetriyi dikkate alan birim kök testlerine de başvurmalıdır. Bu testler uygulanırken metinde testlere ilişskin yoğun teknik detay vermeye ihtiyaç yoktur çünkü bu testler ilgili literatürde yaygın olarak kullanılmakta olduğundan literatürde zaten yerini almıştır.

Açıklama [L2]: Burada seri tüketim-gelir oranı olduğundan reel seri (2005 baz yıllı) almak gerekmez. Hem tüketim hem gelir serisi nominal değişken olabilir. Bu, açıklığa kavuşturulmalıdır. 
edilmiştir. Değişkenin doğal logaritması alınmıştır (bkz. Cook, 2005; Romero-Avila, 2009; Sarantis, Stewart, 1999).

Burada ilk olarak kırılmalı birim kök testlerinden önce karşılaştırma yapılabilmesi amacıyla kırılmayı dikkate almayan birim kök test sonuçlarına yer verilmiştir. Bu amaçla Dickey-Fueller (1979) (ADF) ve Phillips-Perron (1988) (PP) tarafından geliştirilen birim kök testlerine başvurulmuştur. Tüketim-gelir serisine ilişkin ADF ve PP birim kök testi sonuçları Tablo (1)'de özetlenmiştir.

Tablo 1. ADF ve PP Birim Kök Testi Sonuçları

\begin{tabular}{|l|l|l|l|}
\hline \multicolumn{2}{|c|}{ ADF Test İstatistiği } & \multicolumn{2}{c|}{ PP Test İstatistiği } \\
\hline Sabit & Sabit ve trend & Sabit & Sabit ve trend \\
\hline$-1.919(0.32)$ & $-3.33(0.07)$ & $-1.816(0.36)$ & $-3.33(0.072)$ \\
\hline
\end{tabular}

Not: Parantez içerisindeki değerler olasılık değerleridir. ADF testi Schwarz bilgi kriteri (SIC)dikkate alınarak otokorelasyonun bulunmadığı minimum gecikme değerlerine göre hesaplanmıştır. PP testinde ise Newey-West optimal uyarlama gecikmeleridir. MacKinnon (1996) kritik değerleri, sabitli model için $\% 1, \% 5$ ve $\% 10$ anlamlılık düzeylerinde sırasıyla $-3.68,-2.97$ ve -2.62 'dir. Sabitli ve trendli model için ise $\% 1, \% 5$ ve $\% 10$ anlamlılık düzeylerinde sırasıyla $4.32,-3.58$ ve -3.22 'dir.

Tablo 1'de görüldüğü üzere birim kök test istatistiklerinin mutlak değeri sabitli model için \%1, \%5 ve \%10 anlamlılık düzeyleri için MacKinnon (1996) tarafindan hesaplanan kritik değerlerin mutlak değerinden küçüktür. Bu nedenle serinin düzeyde durağan olmadığı sonucuna varılmaktadır. Sabit ve trendli model incelendiğinde ise MacKinnon kritik değerleri $\% 1$ ve $\% 5$ anlamlılık düzeyinde test istatistiklerinden küçüktür. Bu nedenle hem sabit hem de sabit ve trendli model için tüketim-gelir serisinin $\% 1$ ve $\% 5$ anlamlılık düzeyinde birinci farkının durağan, yani I(1) oldukları anlaşılmaktadır.

Tablo 2. ZA Birim Kök Testi Sonuçları

\begin{tabular}{|l|c|c|}
\hline & Model A & Model C \\
\hline Test İstatistiği & -4.03215 & -4.2645 \\
\hline Kırılma Tarihi & 1987 & 1977 \\
\hline Gecikme Uzunluğu & 0 & 0 \\
\hline Kritik Değerler (\%5) & -4.80 & -5.08 \\
\hline
\end{tabular}

Not: Kritik değerler Zivot, Andrews (1992)'den elde edilmiştir. 
Zivot-Andrews birim kök testinden elde edilen sonuçlar ise Tablo 2'de yer almaktadır. Tablo 2'deki veriler incelendiğinde hem Model A hem de Model C için test istatistiklerinin kritik değerlerden mutlak değer olarak küçük olduğu görülmektedir. $\mathrm{Bu}$ sebeple tüketim-gelir serisinin yapısal kırılma olmadan birim köklü olduğunu savunan temel hipotez reddedilememektedir. Böylece $\% 5$ anlamlılık düzeyi için, kırılma ile birlikte tüketim-gelir oranının durağan olmadığı hipotezi reddedilememektedir.

LP testi sonuçları ise Tablo 3'de özetlenmektedir. LP testinde temel hipotez seride yapısal kırılma olmadan birim kökün olduğunu söylemektedir. Alternatif hipotez ise serinin iki yapısal kırılma ile birlikte trend durağan olduğunu ifade etmektedir. Tablo 3'deki sonuçlara göre, ortalama tüketim eğilimi serisinin test istatistikleri Model AA ve Model CC için de kritik değerlerden küçüktür. Bu nedenle seride yapısal kırılma olmadan birim kökün olduğunu ifade eden temel hipotez $\% 5$ anlamlılık düzeyinde reddedilememektedir.

\section{Tablo 3. LP Birim Kök Testi Sonuçları}

\begin{tabular}{|l|c|c|}
\hline & Model AA & Model CC \\
\hline Test İstatistiği & -5.7107 & -6.2185 \\
\hline Birinci Kırılma Tarihi & 1976 & 1973 \\
\hline İkinci Kırılma Tarihi & 2002 & 1986 \\
\hline Gecikme Uzunluğu & 0 & 0 \\
\hline Kritik Değerler (\%5) & -6.1600 & -6.7500 \\
\hline
\end{tabular}

Not: Kritik değerler Ben-David et al. (2003)'ten elde edilmiştir.

Tablo 4. Tek Kırılmalı LM Birim Kök Testi Sonuçları

\begin{tabular}{|l|c|c|}
\hline & Model A & Model C \\
\hline Test İstatistiği & -3.6699 & -3.5000 \\
\hline Kırılma Tarihi & 1982 & 1982 \\
\hline Gecikme Uzunluğu & 2 & 2 \\
\hline Kritik Değerler (\%5) & -3.566 & -4.51 \\
\hline
\end{tabular}

Not: Kritik değerler Lee, Strazicich (2004)'ten elde edilmiştir. Model C için kırılma tarihinin konum değeri $0.5^{\prime}$ tir.

Tablo 4'te ise tek kırılmalı LM testi sonuçları yer almaktadır. Burada kırılma tarihi 1982 olarak tespit edilmiştir. Düzeyde kırılmaya izin veren Model A'da \%5 anlamlılık düzeyi için test istatistiği, kritik değerden büyük olduğundan serinin yapısal

\section{Açıklama [L3]: Bu yorumlardaki ifadeler düzeltilmelidir. Test edilen sıfır hipotezi serinin durağan olmadığını ifade etmektedir. Dolayısıyla yorum "kırılma ile birlikte tüketim-gelir oranının durağan olmadığı hipotezi ret edilememektedir" olmalidır.}

Açıklama [L4]: Bu ifade 'ret edilememektedir' olarak düzeltilmelidir. 
kırılmalar altında birim köklü olduğunu savunan temel hipotez reddedilmektedir. Hem düzeyde hem de eğimde kırılmaya izin veren Model C'ye göre ise, yapısal kırılmalarla birlikte tüketim-gelir oranının birim köklü olduğu sonucuna ulaşılmaktadır.

İki kırılmalı LM testi sonuçlarının özetlendiği Tablo 5'te ise test istatistiği Model A için kritik değerden mutlak değer olarak büyükken Model C için kritik değerden küçük bir test istatistiği ile karşılaşılmaktadır. Bu durumda Model C'de iki yapısal kırılma altında tüketim-gelir oranının birim köklü olduğu temel hipotezi kabul edilmektedir. Sadece düzeyde kırılmaya izin veren Model A dikkate alındığında ise, seri yapısal kırılmalar altında durağandır.

\section{Tablo 5. İki Kırılmalı LM Birim Kök Testi Sonuçları}

\begin{tabular}{|l|c|c|}
\hline & Model A & Model C \\
\hline Test İstatistiği & -3.9831 & -5.3050 \\
\hline Birinci Kırılma Tarihi & 1982 & 1979 \\
\hline İkinci Kırılma Tarihi & 1991 & 1992 \\
\hline Gecikme Uzunluğu & 2 & 2 \\
\hline Kritik Değerler (\% 5) & -3.842 & -5.67 \\
\hline
\end{tabular}

Not: Kritik değerler Lee, Strazicich (2003)’ten elde edilmiştir. Model C için kırılma tarihlerinin konum değerleri sırasiyla 0.44 ve 0.67 'dir.

Kapetanios (2005) tarafından geliştirilen ve çoklu kırılmaya (5 kırılma) izin veren test sonuçları Tablo 6'da yer almaktadır. Hem sabitli, hem de sabitli ve trendli model için uygun kırılma sayısı 1 olarak belirlenmiştir. Çünkü 1 kırılmalı modelin t istatistiği minimum değere sahiptir. 1 Kırılmalı modelin kırılma tarihleri ise sabitli model için 1986 ve sabitli ve trendli model için ise 1976'dır.

Tablo 6. Kapetanios (2005) 5 Kırılmalı Birim Kök Testi Sonuçları

\begin{tabular}{|l|c|c|}
\hline $\mathbf{k}$ & Sabitte Kurılma & (Sabit-Trendde) Kırılma \\
\hline $\mathbf{1}$ & $-4.1292^{*}$ & $-4.2285^{*}$ \\
\hline $\mathbf{2}$ & -4.6017 & -5.8827 \\
\hline $\mathbf{3}$ & -4.6256 & -6.77580 \\
\hline $\mathbf{4}$ & 1000 & 1000 \\
\hline $\mathbf{5}$ & 1000 & 1000 \\
\hline
\end{tabular}

Not: Sabitli ve tek kırılmalı model için $\% 1, \% 5$ ve $\% 10$ anlamlılık düzeylerinde uygun kritik değerler sırasıyla, $-5.338,-4.930$ ve -4.661 'dir. Sabit-Trendli ve tek kırılmalı model için \%1, \%5 ve $\% 10$ anlamlılık düzeylerinde kritik değerler sırasıyla $-5.704,-5.081$ ve -4.820 'dir.

Hacettepe University Journal of Economics and Administrative Sciences Vol 33, Issue 3, 2015

38 
Sabitli model için -4.12 mutlak değer olarak \%10 anlamlılık düzeyindeki -4.66 değerine sahip kritik değerden küçük olduğu için sıfır hipotezi reddedilememektedir. Böylece serinin birim kök içerdiği sonucuna ulaşılmaktadır. Sabitli ve trendli model için ise, -4.22 yine $\% 10$ anlamlllık düzeyindeki -4.82 değerine sahip kritik değerinden mutlak değer olarak küçük olduğu için yine sıfır hipotezi reddedilememektedir. Kısacası seri birim kök içermektedir.

Son olarak Tablo 7'de doğrusal olmayan KSS birim kök testi sonuçlarına yer verilmiştir. Burada maksimum gecikme uzunluğu 4 alınıp, uygun gecikme uzunluğu sabitten arındırılmış model için 0 , sabit ve trendden arındırılmış model için ise 2 olarak belirlenmiştir. Gecikme uzunluğunun tespitinde Campbell ve Perron (1991) tarafindan önerilen gecikme uzunluğu seçme yöntemi kullanılmıştır.

Tablo 7. KSS Testi Sonuçları

\begin{tabular}{|l|c|c|}
\hline Değişken/gecikme sayısı & $t_{N L 1}$ & $t_{N L 2}$ \\
\hline Tüketim/gelir değişkeni & -2.62 & -4.01 \\
\hline $\mathrm{k}$ & 0 & 2 \\
\hline
\end{tabular}

Not: Kritik değerler sabitten arındırılmış model (Case 2) için \%1, \%5 ve \%10 anlamlılık düzeylerinde sırasıyla $-3.48,-2.93,-2.66$ 'dır. Sabit ve trendden arındırılmış model (Case 3 ) için ise $\% 1, \% 5$ ve $\% 10$ anlaml1lk düzeylerinde sirasıyla $-3.93,-3.40$ ve -3.13 'dür. k; gecikme sayısını göstermektedir.

Sürecin sadece sabit içerdiğini gösteren $t_{N L 1}$ istatistiği $\% 10$ anlamlıl1k düzeyinde mutlak değer olarak kritik değerden küçük olduğu için $H_{0}: \theta=0$ temel hipotezi $H_{1}: \theta \succ 0$ şeklindeki alternatif hipoteze karşın reddedilememektedir. Dolayısıyla yalnızca sabiti içeren model için süreç, birim kök içeren doğrusal bir süreçtir.

Sürecin hem sabit, hem de trend içerdiğini gösteren $t_{N L 2}$ istatistiği $\% 1$ anlamlılık düzeyinde mutlak değer olarak kritik değerden büyük olduğu için $H_{0}: \theta=0$ temel hipotezi $H_{1}: \theta \succ 0$ alternatif hipotezine karşı reddedilmektedir. Dolayısıyla, $t_{N L 2}$ istatistiğine göre süreç, durağan bir ESTAR modele uygunluk göstermektedir. 
Sonuç olarak ZA testine göre tüketim-gelir oranı yapısal kırılma olmadan birim köklü olarak tespit edilmiştir. Benzer şekilde LP testi de hem Model AA hem de Model CC için, yapısal kırılma olmadan birim kökün olduğunu ifade eden temel hipotezi kabul etmektedir. Bir ve iki kırılmalı LM testine göre sadece düzeyde kırılmaya izin veren Model A'da tüketim-gelir oranı durağan iken, hem düzeyde hem de eğimdeki kırılmayı dikkate alan Model C'de tüketim-gelir oranı birim köklüdür. Çoklu kırılmaya izin veren Kapetanios $v d$. (2005)'nin testi ile KSS testinin sabitli modeline göre tüketim- gelir oranı yine birim kök içermektedir. KSS testinde sabit ve trendli model dikkate alındığında ise seri durağan bir ESTAR süreci izlemektedir.

Romero-Avila (2008) tarafından belirtildiği üzere makro ekonomik serilerde stokastik ve deterministik trend arasındaki fark, şokun doğasını anlamak için önem arz etmektedir. Bu nedenle eğer seri durağan değil ise ilgili değişken, cari değeri, geçmiş değerlerine sıkı bir bağımlılığa sahip olduğu için yörünge bağımlıdır (path dependent). Bu durumda geçici şoklar, etkilerin zaman boyu birikmesinden ötürü değişkeni sürekli etkilemektedir. Tersine eğer seri durağan ise, etkilerin zamanla kaybolmasında ötürü geçici şoklar değişken üzerinde sürekli etkilere sahip olmayacaktır.

Bu çalışmadan elde edilen sonuçlar dolayısıyla bir ve iki kırılmalı LM testinde Model A ile KSS testinde sabit ve trendli model haricinde tüketim-gelir oranında birim kökün varlığı, bu serinin tahmin edilebilir bir düzey etrafında salınım yapmadığına işaret etmektedir. Bu bağlamda tüm şoklar sürekli olarak APC'yi sabit bir değere geri dönme eğilimi olmaksızın değiştirmektedir. Bu durumda tüketim ve gelir arasında yapısal bir ilişki kurulamamakta ve böylece APC bir uzun dönem dengesine sahip olamamaktadır (Baykara, Telatar, 2012: 2).

\section{Sekil 1. Tüketim-Gelir Oranı}

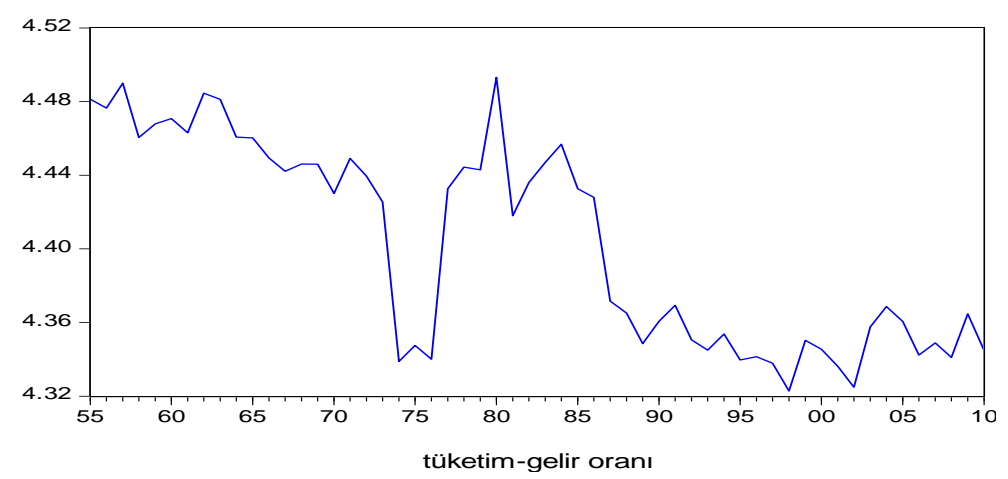

Hacettepe University Journal of Economics and Administrative Sciences Vol 33, Issue 3, 2015

40 
Yukarıdaki grafikte veri setine ilişkin grafik yer almaktadır. Birim kök testlerinde tespit edilen kırılma tarihlerine göz attığımızda ise genellikle kriz dönemlerine işaret ettiği görülmektedir. Örneğin, 1973-1974 yılları petrol krizinin yaşandığı yıllardır.1979 yılında yine Petrol krizi ve Türk lirasında devalüasyon söz konusudur. Ayrıca 1979 yılında seçimler gerçekleşmiştir. 1980 istikrar programının ve özellikle bu programda benimsenen "serbest faiz oranı"nın tasarrufu yükselterek talebi kısma etkisi ile ücretlerin dondurulması kararının enflasyon oranını 1981 ve 1982 yılında düşürmesinden bahsedilebilir. 1986 yılına gelindiğinde ise, Türk parası devalüe edilmiştir. 1991 yılında Irak Savaşı ve Körfez Krizi yaşanmıştır. 1992 yılında ise hükümet değişmiş ve Erzincan depremi meydana gelmiştir. Türkiye'de yine 2001-2002 yılında büyük bir ekonomik kriz yaşanmıştır. Yine 2002 yılı seçim yılıdır.

\section{SONUÇ}

Tüketim-gelir oranının uzun dönem özellikleri son dönemde ampirik çalışmalarda dikkat çeken konular arasındadır. Tüketim-gelir oranının ya da APC' nin durağan olup olmaması, tüketim ve gelir arasında uzun dönemde bir denge ilişkisinin varlığı konusunda bilgi verecektir. Böylece bireylerin tüketim ve tasarruf davranışlarına ilişsin çıkarımlar yapılması söz konusu olabilecektir.

Bu çalışmada tüketim-gelir oranının durağanlığı Türkiye için sınanmaktadır. Bu amaçla 1955-2010 dönemine ilişkin y1llık veriler Zivot ve Andrews (1992), Lumsdaine ve Papell (1997), Lee ve Strazicich $(2003,2004)$, Kapetanios $v d$. (2005) tarafindan geliştirilen yapısal kırılmalı birim kök testleri ve Kapetanios $v d$. (2003) tarafından geliştirilen doğrusal olmayan KSS birim kök testi ile analiz edilmiştir. ZA ve LP testine göre tüketim-gelir oranında, yapısal kırılma olmadan birim kökün olduğunu ifade eden temel hipotez kabul edilmektedir. Bir ve iki kırılmalı LM testine göre ise farkl sonuçlara ulaşılmıştır. Burada düzeyde kırılmaya izin veren Model A'da tüketim-gelir oranı durağan iken, hem düzeyde hem de eğimdeki kırılmayı dikkate alan Model C'de tüketim-gelir oranı birim köklüdür. Çoklu kırılmaya izin veren birim kök testinde de serinin birim köklü olduğu tespit edilmiştir. KSS testinin sabitli modeli dikkate alındığında serinin doğrusal birim kök süreci izlediği gözlenmiştir. KSS testinin hem sabit hem de trendli modeline göre ise tüketim-gelir oranı durağan bir ESTAR modeli özelliği taşımaktadır. Bu durumda genel itibariyle Türkiye örneği için APC'nin uzun dönemde bir sabite yakınsamadığı ifade edilebilecektir. Bu sebeple politik şokların hanehalkının tüketim ve tasarruf davranışları üzerinde kalıcı etkilere sahip olacağı söylenebilir. 
Ayrıca durağan olmayan APC'nin varllğına dair bu bulgular tüketicilerin ileriye dönük olduğunu savunan nispi gelir hipotezi, sürekli gelir hipotezi ve ömür boyu gelir hipotezlerin Türkiye için geçerli olmadığını göstermektedir. Buna karşın, elde edilen sonuçlar Keynesyen (1936)'in “Mutlak Gelir Hipotezi”, Deaton (1977)'un 'Zorunluİstek Dışı Tasarruf Teorisi” ve Marksist "Yetersiz Tüketim Teorisi” (Underconsumption Theory) ile uyumludur. Bu sebeple Türkiye'deki tüketicilerin miyopik özellikler taşıdıkları ortaya çıkmaktadır. İlaveten, otoritelerin para politikasına kıyasla maliye politikası vasıtasıyla kısa dönemi önemseyen tüketicilerin cari tüketimini etkilemede daha etkili olacağı söylenebilir.

Bir başka ifade ile Sürekli Gelir, Ömür Boyu Gelir ve Nisbi Gelir Hipotezlerine göre tüketim sürekli ya da ömür boyu gelirin bir fonksiyonudur, bu nedenle tüketiciler ileri bakışlıdır. Tüketiciler için ise beklentiler önemli rollere sahip olup, şokların kaynağı önem arz etmektedir. Tüketiciler, şokun sürekli ya da geçici olması durumunda farklı tepkiler vereceklerdir. Tüketim, geçici şoklardan ziyade sürekli değişikliklerden etkilenmektedir. Örneğin, vergilerdeki geçici değiş̧iklikler tüketim üzerinde etkili olamayacağı için maliye politikaları etkinlik gösteremeyecektir. Ayrıca tüketicilerin tüketim düzleştirmesi yapmaları ve ileri bakışlı olmaları APC'nin uzun dönemde sabit kalmasını sağlamaktadır. Fakat bu çalışmanın bulguları tarafından da desteklenen Mutlak Gelir Hipotezine göre ise tüketiciler sadece tüketimi cari gelirin bir fonksiyonu olarak görmektedirler. Kısa dönemli bir bakışa sahiptirler. Cari gelirdeki değişiklikler tüketim kararlarını etkilemektedir. Tüketim kararlarının zamanlar arası yayamayıp dolayısıyla tüketim düzleştirmesi yapamadıkları için de APC durağan olmamakta ve gittikçe azalan bir seyir izlemektedir. Ayrıca bu durumda, cari gelirde örneğin vergilerin değiştirilmesi yolu ile yapılan değişiklikler tüketim üzerinde etkili olacağı için maliye politikaları daha etkin olacaktır. Para politikalarının uygulanmasında gecikmelerin (lag) söz konusu olması nedeniyle gelir üzerindeki etkileri daha uzun vadede görüleceğinden ötürü, maliye politikaları ile beklenen değişikliği kısa vadede elde etmek daha kolay olacaktır.

\section{KAYNAKÇA}

Ando, A., F. Modigliani (1963), "The Life-cycle Hypothesis of Saving: Aggregate Implications and Tests", American Economic Review, 53, 55-84.

Baykara, S., E. Telatar (2012), "The Stationarity of Consumption-Income Ratios with Nonlinear and Asymmetric Unit Root Tests: Evidence from Fourteen Transition Economies", Hacettepe University Department of Economics Working Papers, No: 20129. 
Ben-David, D., R. Lumsdaine, D.H. Papell (2003), "Unit Root, Postwar Slowdowns and LongRun Growth: Evidence from Two Structural Breaks", Empirical Economics, 28(2), 303-319.

Bjornland, H.D. (1999), "Structural Breaks and Stochastic Trends in Macroeconomic Variables in Norway", Applied Economics Letters, 6, 133-138.

Blinder, A.S., A. Deaton, R.E. Hall, R.G. Hubbard (1985), “The Time Series Consumption Function Revisited", Brookings Papers on Economic Activity, 2, 465-521

Campbell, J.Y. (1987), "Does Saving Anticipate Declining Labor Income?, An Alternative Test of the Permanent Income Hypothesis", Econometrica, 55, 1249-1273.

Campbell, J.Y., P. Perron (1991) "Pitfalls and Opportunities: What Macroeconomists Should Know About Unit Roots”, NBER Macroeconomics Annual, 6, 141-201.

Caner, M., B.E. Hansen (2001), “Threshold Autoregression with A Unit Root", Econometrica, 69(6), 1555-1596.

Carrion-i-Silvestre, J.L., T. Del Barrio, E. López-Bazo (2005), "Breaking The Panels: An Application to the GDP Per Capita", The Econometrics Journal, 8,159-175.

Cerrato, M., C. De Peretti, R. Larsson, N. Sarantis (2009) “A Nonlinear Panel Unit Root Test Under Cross Section Dependence”, Discussion Paper 2009-28, Glasgow: Department of Economics, University of Glasgow.

Cerrato, M., De Peretti, C. Stewart, (2013), "Is the Consumption-Income Ratio Stationary?, Evidence from Linear and Nonlinear Panel Unit Root Tests for OECD and NonOECD Countries", Manchester School, 81, 102-120.

Choi, I. (2001), "Unit Root Tests For Panel Data", Journal of International Money and Finance, $20,249-272$

Cook, S. (2002), “Asymmetric Mean-Reversion in the Consumption-Income Ratio: Evidence from OECD Economies", Applied Economics and International Development, 2, 27 34.

Cook, S. (2003), "The Nonstationarity of the Consumption-Income Ratio: Evidence from More Powerful Dickey-Fuller Tests", Applied Economics Letters, 10, 393-395.

Cook, S. (2005), "The Stationary of Consumption-Income Ratios: Evidence from Minimum LM Unit Root Testing”, Economics Letters, 89(1), 55-60.

Deaton, A.S. (1977), "Involuntary Saving through Unanticipated Inflation", American Economic Review, 67, 899-910.

Dickey, D.A., W.A. Fuller (1979), "Distribution of the Estimators for Autoregressive Time Series with a Unit Root", Journal of the American Statistical Association, 74, 427-31.

Drobny, A., S.G. Hall (1989), “An Investigation of the Long-run Properties of Aggregate Nondurable Consumers' Expenditure in the United Kingdom", Economic Journal, 99, 454-460. 
Duesenberry, J.S. (1952) Income, Saving and the Theory of Consumer Behavior, Cambridge Mass: Harvard University Press.

Fallahi, F. (2012), “The Stationarity of Consumption-income Ratios: Evidence from Bootstrapping Confidence Intervals", Economics Letters, 115, 137-140.

Friedman, M. (1957), A Theory of the Consumption Function, Princeton: Princeton University Press.

Giray, G. (2013), "Stochastic Properties of the Consumption-Income Ratios in Central and Eastern European Countries", Journal of Economics and Business, 31(2), $193-207$.

Gomes, F.A.R., D.S. Franchini (2009) "The Stationarity of Consumption-Income Ratios: Evidence From South American Countries”, Economia Aplicada, 13, 463-479.

Hadri, K. (2000), "Testing for Stationarity in Heterogeneous Panel Data", The Econometrics Journal, 3, 148-161.

Hall, S.G., K.D. Patterson (1992), "A Systems-Approach to the Relationship between Consumption and Wealth", Applied Economics, 24, 1165-1171.

Harris, R.D.F., E. Tzavalis (1999), "Inference for Unit Roots in Dynamic Panels where the Time Dimension is Fixed", Journal of Econometrics, 91, 201-226.

Horioka, C.Y. (1997), "A Cointegration Analysis of the Impact of the Age Structure of the Population on the Household Saving Rate in Japan", Review of Economics and Statistics, 79, 511-516.

Im, S.K., H.M. Pesaran, Y. Shin (1997), "Testing for Unit Roots in Heterogeneous Panel”, Cambridge: Department of Applied Econometrics, University of Cambridge.

Im, K.S., J. Lee, M. Tieslau (2005), "Panel LM Unit Root Tests with Level Shifts", Oxford Bulletin of Economics and Statistics, 67, 393-419.

Jin, F. (1995), "Cointegration of Consumption and Disposable Income: Evidence from Twelve OECD Countries”, Southern Economic Journal, 62, 77-88.

Kapetanios, G., Y. Shin, A. Snell (2003), "Testing for a Unit Root in the Nonlinear STAR Framework", Journal of Econometrics, 112, 359-379.

Kapetanios, G. (2005), "Unit-Root Testing against the Alternative Hypothesis of Up to M Structural Breaks", Journal of Time Series Analysis, 26, 123-133

Keynes, J.M. (1936), The General Theory of Employment, Interest and Money, London: MacMillan.

King, R.G., C.I. Plosser, J.H. Stock, M.W. Watson (1991) "Stochastic Trends and Economic Fluctuations", American Economic Review, 81, 819-840.

Lee, J., M. Strazicich (1999) “Minimum LM Unit Root Test”, Department of Economics, Faculty Research Paper, No: 9932, Technical Report, University of Central Florida.

Lee, J., M. Strazicich (2003), "Minimum LM Unit Root Test with Two Structural Breaks", Review of Economic and Statistics, 85(4), 1082-1089. 
Lee, J., M.C. Strazicich (2004), "Minimum LM Unit Root Test with One Structural Break", Department of Economics Working Papers, No: 04-17, Appalachian State University.

Lettau, M., S. Ludvigson (2001), "Consumption, Aggregate Wealth, and Expected Stock Returns", Journal of Finance, 56, 815-849.

Levin, A., C.F. Lin, C. Chu (2002), "Unit Root Tests in Panel Data: Asymptotic and Finitesample Properties", Journal of Econometrics, 108, 1-24.

Liao, S., M. Huang, L. Wang (2011), "Mean-reverting Behavior of Consumptionincome Ratio in OECD Countries: Evidence from SURADF Panel Unit Root Tests", Economics Bulletin, 31, 679-686.

Lumsdaine, R. L., D.H. Papell (1997), "Multiple Trend Breaks and The Unit Root Hypothesis", Review of Economics and Statistics, 79(2), 212-18.

Mackinnon, J. (1996), "Numerical Distribution Functions for Unit Root and Cointegration Tests", Journal of Applied Econometrics, 11, 601-618.

Maddala, G., S. Wu (1999), “A Comparative Study of Unit Root Tests with Panel Data and A New Simple Test”, Oxford Bulletin of Economic and Statistics, 61, 631-652.

Molana, H. (1991), "The Time Series Consumption Function: Error Correction, Random Walk and the Steady State", Economic Journal, 101, 382-403.

Nelson, C.R., C.R. Plosser (1982), "Trends and Random Walks in Macroeconomics Time Series: Some Evidence and Implications”, Journal of Monetary Economics, 10, 139-162.

Ng, S., P. Peron (2001), "Lag Length Selection and the Construction of Unit Root Tests Withgood Size and Power", Econometrica, 69, 1519-1554.

Ng, S., P. Perron (1995), "Unit Root Tests in ARMA Models With Data Dependent Methods for Selection of the Truncation Lag", Journal of the American Statistical Association, 90, 268-281.

Park, H., W. Fuller (1995), “Alternative Estimators and Unit Root Tests for the Autoregressive Process”, Journal of Time Series Analysis, 16, 415-29.

Perron, P. (1989), "The Great Crash, The Oil Price Shock, and The Unit Root Hypothesis", Econometrica, 57(6), 1361-401.

Pesaran, M.H. (2003), “A Simple Panel Unit Root Test in the Presence of Cross- Section Dependence", mimeo, Cambridge University.

Pesaran, M.H. (2007), "A Simple Panel Unit Root Test in the Presence of Cross Section Dependence", Journal of Applied Econometrics, 22, 265-312.

Phillips, P.C.B, P. Perron (1988) “Testing for a Unit Root in Time Series Regressions", Biometrika,75, 335-346.

Romero-Ávila, D. (2008), “A Confirmatory Analysis of the Unit Root Hypothesis for OECD Consumption-Income Ratios", Applied Economics, 40, 2271-2278. 
Romero-Ávila, D. (2009), “Are OECD Consumption-Income Ratios Stationary After All?”, Economic Modelling, 26, 107-117.

Sarantis, N., C. Stewart (1999), "Is the Consumption-Income Ratio Stationary? Evidence from Panel Unit Root Test”, Economics Letters, 64, 309-314.

Shin, D., B. So (2001), "Recursive Mean Adjustment for Unit Root Tests", Journal of Time Series Analysis, 22, 595-612.

Slesnick, D.T. (1998), "Are Our Data Relevant to the Theory? The Case of Aggregate Consumption", Journal of Business and Economic Statistics, 16, 52-61.

Smith, L.V., S. Leybourne, T. Kim, P. Newbold (2004), "More Powerful Panel Data Unit Root Tests With An Application to the Mean Reversion in Real Exchange Rates", Journal of Applied Econometrics, 19, 147-170.

Sollis, R., S. Leybourne, P. Newbold (2002), "Tests For Symmetric And Asymmetric Nonlinear Mean Reversion in Real Exchange Rates", Journal of Money, Credit and Banking, 34, 686-700.

Taylor, M.P., L. Sarno (1998), “The Behaviour of Real Exchange Rates During The Post-Bretton Woods Period", Journal of International Economic, 46, 281-312.

Tsionas, E., D. Christopoulos (2002), "Non-Sationarity in the Consumption- Income Ratio: Further Evidence from Panel and Asymmetric Unit Root Tests", Economics Bulletin, $3,1-5$.

Ungern-Sternberg, T.V. (1986), "Inflation and the Consumption Function”, Weltwirtschftliches Archiv, 122, 741-744.

Yılancı, V., F. Zeren, F., A. Arı (2013), “Tüketim-Gelir Oranı Güneydoğu Asya Ülkelerinde Durağan Mı?: Panel Birim Kök Testi”, Yönetim ve Ekonomi Araştırmaları Dergisi, 21, 1301-39.

Zivot, E., D.W.K. Andrews (1992), "Further Evidence on The Great Crash, the Oil Price Shock, and The Unit Root Hypothesis", Journal of Business and Economic Statistics, 10(3), 251-70.

Hacettepe University Journal of Economics and Administrative Sciences 